\title{
Challenges on Cattle Breeding of Smallholder Famer Toward 4.0 Era
}

\section{(Tantangan Pemuliaan Sapi dari Petemak Kecil Menuju Era Industri 4.0)}

\author{
Boon P \\ Indonesia-Australia Commercial Cattle Breeding Program
}

\begin{abstract}
A project within the Indonesia-Australia Partnership on Food Security in Red Meat and Cattle Sector has been established in expanding the commercial-scale beef cattle breeding industry. There are three potential models for cattle breeding tested through partnership such as Integrated Oil Palm and Cattle Production (SISKA), Open-Grazing and Smallholder Cutand-Carry. To support Indonesian cattle breeding investors toward industry 4.0, some software has been developed: CALPROS, CALPROF and CALFIN used for monitoring and evaluation available online. Another application, SI PINTAR, is to record and identify livestock with Radio-Frequency Identification (RFID) recording and Global Positioning Systems (GPS) tracker to monitor livestock in real time basis. Applying those tools has proved increase benefits in cattle breeding business including smallholders and recommended for future use toward industry 4.0.
\end{abstract}

Key words: Cattle, breeding, livestock

\begin{abstract}
ABSTRAK
Suatu kemitraan antara pemerintah Indonesia dan Australia dibentuk untuk mendukung ketahanan pangan berkaitan dengan pengembangan sektor industri peternakan sapi potong komersial. Model potensial pembiakan sapi potong kemitraan meliputi Sistem Integrasi Kelapa Sawit dan Sapi Potong (SISKA), Open-grazing (Sistem penggembalaan) dan Cut-andCarry (potong-ambil) peternak kecil. Untuk mendukung perusahaan pembiakan sapi potong menghadapi industri 4.0, beberapa software telah dikembangkan seperti CALPROS, CALPROF dan CALFIN yang digunakan untuk monitoring dan evaluasi yang dapat diakses secara online. Aplikasi lainnya, SI PINTAR, mencatat identifikasi ternak menggunakan sistem Radio-Frequency Identification (RFID) dan penelusuran Global Positioning Systems (GPS) guna memonitor ternak berbasis real time (waktu sesungguhnya). Pemanfaatan peralatan tersebut terbukti berguna dalam perusahaan peternakan sapi potong termasuk peternak kecil dan penggunaannya ke depan menyongsong industri 4.0.
\end{abstract}

Kata kunci: Sapi potong, pembiakan, ternak

\section{INTRODUCTION}

Indonesia-Australia Commercial Cattle Breeding (IACCB) program is a project within the Indonesia- Australia Partnership on Food Security in Red Meat and Cattle Sector. IACCB's goal is to expand the commercial-scale beef cattle breeding industry in Indonesia. It does this by partnering with private sector project partners (farmer groups, farmer cooperatives and plantations) to test three cattle breeding models (1) Integrated Oil Palm and Cattle Production; (2) Open-Grazing and (3) Smallholder Cut-and-Carry 
across 8 project locations from the high rain fall zones in the west Sumatera to the dryer tropics of East Indonesia. These systems and locations have been chosen because they cover the range of business structure with the greatest likelihood of success, over the greater opportunities for industry expansion and most closely reflect the challenges and issues likely to be encountered.

IACCB has documented the experiences in a manual consisting of four technical modules to assist managers and investors start and manage commercial cattle breeding in Indonesia. The modules include:

- Economics of Commercial Cattle Breeding.

- Cattle Breeding Herd Management.

- Pastures and Pasture Development.

- Monitoring and Evaluation of a Cattle Breeding Enterprise.

The IACCB has developed a range of monitoring and evaluation forms for its own use. The forms are broadly applicable to most cattle breeding enterprise and can be amended as required to suit specific requirements (available online).

IACCB has developed three tools to support Indonesian cattle breeding investors toward industry 4.0. The tools are CALPROS and CALPROF. CALPROS is Cow-calf Operations Productivity Spreadsheet is for small or new breeders to monitor the productivity of breeders and their progeny. Based on Microsoft Excel, it can be used by new actors in the cattle breeding industry to monitor their operations. CALPROF is Cowcalf Operations Software, produced in collaboration with a local software developer, enables a company to track progress and profitability, and generates a record of key performance indicators. CALFIN, a spread sheets to support investors and cattle breeding businesses in making investment decision.

IACCB has collaboration with some stakeholders and developed some others new application. The new application are SI PINTAR, which aim to record and identify livestock with Radio-Frequency Identification (RFID) recording and Global Positioning Systems (GPS) tracker to monitor livestock in real time basis.

Silvo pasture (grassing of cattle under commercial forest) was also targeted due to the extensive land area in Indonesia under commercial forest leases. However, suitable partner and project were unable to be identified. IACCB will progressively generate valuable lesson and technical guidance, which will be made available for all potential investors. There are several potential models for cattle breeding that are possible in Indonesia. The production models are as follows:

\section{Integrated oil palm and cattle production (SISKA)}

An estimated 10 million ha of Indonesia is devoted to palm-oil production, largely in Sumatera and Kalimantan. Palm oil operation offer significant commercial potential because the land is already purchased and in use for palm oil production. Cattle breeding under palm oil can provide owners with an additional income stream, and may reduce production cost and increased productivity. IACCB is testing these proposition in four locations:

1. Buana Karya Bakti (BKB) in Satui, Tanah Bumbu District, South Kalimantan Province.

2. Kalteng Andinipalma Lestari (KAL) in central Seruyan Sub-district, Seruyan District, Central Kalimantan Province.

3. Bio Nusantara Technology (BNT) in Pondok Kelapa Sub district, North Bengkulu District, Bengkulu Province. 
4. Superindo Utama Jaya (SUJ) in North Metro Sub-district, Metro City, Lampung Province.

The selection of four project with quite different operating environments is allowing IACCB to identify the key challenges and solution to commercial sustainability within the integrated oil palm project.

Three out of four SISKA (Breeding cattle in oil palm plantation partners are expending their herd, via selecting productive heifers and Bulls from their year 1 progeny, and through significant investment in more breeding stock. Their aim is to achieve improved economies of scale. Our animal health advisor provided cattle selection on - the - Job training for each partner.

Cash-flow has become especially important for SISKA partners as palm-oil prices have fallen substantially. As a result, three SISKA partners have started fattening trials with year 1 bulls and heifers not selected for breeding, using waste-product from the palm-oil production process.

Targeting the Qurban market at Iedul Adha resulted in premium prices for the cattle. In two locations, the initial trial resulted in average daily gain of $0.7 \mathrm{~kg} / \mathrm{head} /$ day with relatively cheap concentrate composed of local product. These results are encouraging but could be improved to improve the cost of gain.

The important of enterprise data management is well-understood by SISKA manager. Consequently the three remaining companies in the program are installing the CALPROF software and integrating it with their plantation software to read more about how advanced data management processes are helping to transform plantation management practices in Indonesia.

\section{Open-grassing}

These system involves the grassing of cattle on improved pastures and forage crops combined with intensive breeding operation in cattle yards (breed lots). Much of the land in Sulawesi and East Indonesia is ideal for these systems. Opprtunities to establish project in these regions were some what limited, due to difficulty of delivery of Australian Cattle to the sites. However, IACCB partner was selected, namely Cahaya Abadi Petani (CAP) in Desa Sai Jelai, Tanah Laut district in South Kalimantan Province.

There is nothing more important than increasing the quantity of high quality pasture in an open-grassing model. After several trials, our open-grassing partner CAP has successfully established 15 ha of improved pasture (Paspalum Ubon and Mulatto II) on their 100-ha farms. A CAP oil palm producing neighbor, after observing the reduction of weeds from grassing, offered 100 ha of young oil palm to grass their cattle, creating a mixed open-grassing and SISKA pilot. Substantially more feed reserved is now available for CAP which should ensure sufficient feed supply in the coming dray session.

CAP has maintained an ideal BCS (BCS $\geq 2.6$ ) for $80-90 \%$ of its herd for the first month of 2019. Year-to-date (up to June) conception is $72 \%$ and winning $59 \%$, both closed to the target rates. A Commercial Viability Assessment will be conducted in September 2019 (year 2 of the project) that will conclusively test these indicative findings.

\section{Cut and carry smallholder group}

Almost all breeding cattle in Indonesia are owned by individual farmers with very small herds. IACCB works with farmer cooperatives with collectively own and manage cattle and facilities. This breeding system involves small farmers cutting forage from 
their own land and carrying it to a breed lots where mating, calving and growing occurred. IACCB selected 3 farmer cooperatives:

1. P4S-Karya Baru Mandiri in Kumai sub-district, West Kota Waringin district, Central Kalimantan.

2. Sentra Peternakan Rakyat Megajaya (SP-MJ) in Kasiman Sub-District, Bojonegoro District, East Java Province.

3. Koperasi Produksi Ternak - Maju Sejahtera (KPT-MS) in Tanjungsari Subdistrict, South Lampung District, Lampung Province.

These projects differ in terms of location, cooperative structure and financial capacity offering valuable lesson for achieving commercial sustainability.

IACCB proven that strong fertility of Brahman Cross under tropical condition can be achieved in smallholder breed lots, but this is highly dependent on intensive and strong management. Calving interval between first and second calves a key measure of productivity, were under 15 months for $80 \%$ of the herd and under 18 months for $98 \%$ of the herd. The interval for the second and third calves has been 12 months for 43 of the herds. These results bode well for commercial viability, with the important caveat that consistently maintaining strong management in communal systems is very challenging.

Even though our pilot farmer groups and cooperative have considerable experience breeding Bali cattle and PO (ongole breed) using traditional model, scaling-up from a small herd to managing significant numbers big-framed Brahman Cross cattle has been challenging. The above results in well-managed small holder enterprises are impressive for communal breed lots but substantial challenges remained. Maintaining herd BCS is challenging due to the inconsistency in feed quality and quantity due to inconsistence financial resources. Fluctuation in BCS impacts on other productivity KPIs. Conception rates fluctuated between $95 \%$ in well-managed partner compare to $73 \%$ in less wellmanaged enterprises. The same variation is seen in calving rates that fluctuated between $94 \%$ and only $51 \%$ and winning rates that varied between $87 \%$ and $68 \%$.

Preparations are now being made to gradually face-out from our two initial cut-andcarry partners. These will include the hand-over of cattle, a decrease in intensive technical support, the hand-over of technical support to the Local Government Livestock Services, and communication of key lesson learnt at a national conference on Smallholder cattle breeding in February or March on 2020.

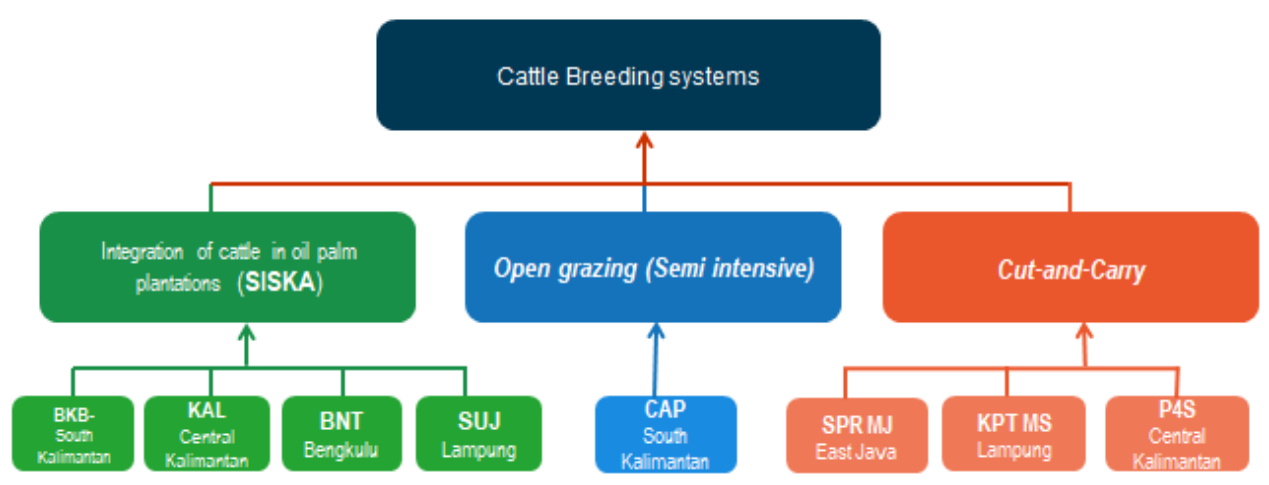

Figure 1. Cattle breeding systems 


\section{CONCLUSION}

Indonesia has three potential models for cattle breeding tested through partnership such as Integrated Oil Palm and Cattle Production (SISKA), Open-Grazing and Smallholder Cut-and-Carry. To support Indonesian cattle breeding investors toward industry 4.0, some software has been developed: CALPROS, CALPROF and CALFIN, SI PINTAR, with RFID recording and GPS tracker. Applying those tools has proved increase benefits in cattle breeding business including smallholders and recommended for future use toward industry 4.0 . 